\title{
Determination of Methane Desorption Zone for the design of a drainage borehole Pattern (Case Study: E4 Panel of the Tabas Mechanized Coal Mine, Iran)
}

Rudarsko-geološko-naftni zbornik

(The Mining-Geology-Petroleum Engineering Bulletin) UDC: $622: 08$

DOI: 10.17794/rgn.2021.1.6

Original scientific paper

\author{
Ali Hosseini'; Mehdi Najafi ${ }^{2}$ \\ ${ }^{1}$ Department of Mining and Metallurgical Eng., Yazd University, Yazd, Iran. Email: Ali.hosseini4126@gmail.com, \\ https://orcid.org/0000-0003-2870-9460 \\ ${ }^{2}$ Department of Mining and Metallurgical Eng., Yazd University, Safayieh, P.O. Box: 89195-741, Yazd, Iran. \\ Email: mehdinajafi@yazd.ac.ir,https://orcid.org/0000-0002-1609-3702
}

\begin{abstract}
Underground coal mining is known as one of the major sources of methane emissions which mainly occurs after underground coal extraction. Rock strata in-situ methane can potentially be the most significant hazard in coal mining operations. To prevent or minimize the risks of methane emissions, methane drainage approaches have been adopted by coal mines. Rock mass methane drainage is the most efficient and effective approach toward controlling methane hazards as it prevents and reduces the frequency of methane emissions, outflows into the working area and sudden outbursts of methane and rocks. The method includes drilling boreholes from the tailgate side to the unstressed zone in the roof and floor strata above and below a working coal seam. The coal seam gas content in Tabas Parvadeh I is estimated to be about $16 \mathrm{~m}^{3} / \mathrm{t}$, which is relatively high. Based on exploration data, five distinct coal seams have been identified (B1, B2, $C_{1}, C_{2}$ and $D$ ) at the coal deposit and currently $C_{1}$ is being worked. Considering the high value of $C_{1}$ gas content and surrounding rocks, the Methane Drainage System (MDS) has been utilized for gas drainage. This paper tries to determine the desorption area which is essential and helpful for the selection of an effective drilling pattern into the adjacent coal seams. In this study, the methane drainage zone in the E4 panel of the Tabas coal mine was calculated using experimental equations and a drainage borehole pattern was determined.
\end{abstract}

\section{Keywords:}

Coal seam, Methane drainage, Desorption zone, Borehole, Longwall mining, Tabas coal mine.

\section{Introduction}

Methane as a greenhouse gas constitutes $17 \%$ of the total anthropogenic greenhouse gas emissions. Underground coal mines are a major source of methane and methane emission from coal mining mainly occurs following the exploitation of underground mines (Dingqi, 2016). The most common mining method used in coal mines is longwall mining, which leads to a relatively high coal output and advance rates. The history of coal mining shows that methane released from the rock mass to the longwall area has been the major reason for numerous mining disasters. Methane emission in coal mines has caused very serious accidents alongside methane and coal dust explosions (Borowski et al., 2018). Coal mining operations in great depths are encountered with difficult geological and mining conditions and threatened by natural hazards, one of the major hazards being the methane emissions associated with the presence of methane in the rock strata and its release during mining operations (Borowski et al., 2009).

To prevent risks of high coalbed methane content, using effective methane drainage systems is essential. Dif-

Corresponding author: Mehdi Najafi

mehdinajafi@yazd.ac.ir ferent methods of methane drainage in longwalls have been used in coal mines and as a result, a wide range of factors affecting the selection of an adequate methane drainage system have been developed. Currently, premining drainage and post mining methane drainage is being used in coal mines. The advantages of coalbed degasification are as follows (Szlazak et al, 2014):

- safety: methane drainage through pipelines results in reducing methane emissions into a working area and roadways and prevents or minimizes explosion hazards,

- ecology: it reduces methane emissions into the atmosphere and helps to minimize the mine anthropogenic effects on the environment,

- economy: methane drainage results in lower power consumption due to a reduction in longwall ventilation air flow rate and higher longwall efficiency and power generation (Ilyashov et al, 2019; Sobolev et al, 2017).

To increase safety in many gassy coal mines throughout the world, methane drainage is an inevitable option. Since reserves of natural gas could be exhausted within the foreseeable future, attention has been focused on methane gas drainage from coal seams as an economic 
Worked out coal seam

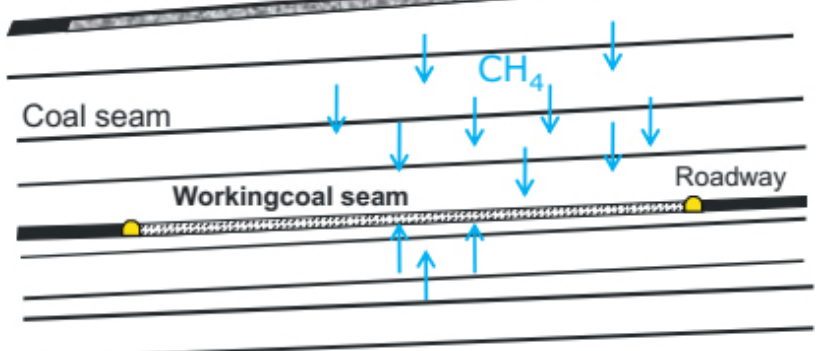

Figure 1: Methane emission from a mining seam (Obracaj et al., 2016)

alternative. Methane emissions from coal during mining result from various mining operations. Methane emissions into the environment of the longwall during coal exploitation come from: 1) an exploited coal seam, 2) underlaying and overlaying coal seams of a working panel, and/or 3) goafs behind the working face, which are connected to the longwall environment (Lama et al, 1987; Obracaj et al, 2016; Szlazak et al, 2014). The sources of methane emissions in mines are shown in Figure 1.

Gas emission from the seam being worked mainly takes place at the exposed faces. The rate of gas emission is dependent on the advance rate, coal seam gas content and coal permeability. Research has studied the subject of desorption zones in longwall mining. Szlazak reviewed the different methane drainage approaches in Poland. They introduced equations and formulas for the identification of a desorption zone (Szlazak et al, 2014). Szlazak studied the effects of methane drainage from overlaying strata with a U-shaped ventilation system (Szlazak et al, 2016). They identified methane desorption zones for the implementation of methane drainage in the adjacent strata. Qingdong proposed a three-zone conceptual model in overlying strata to provide a complete and simple understanding of the coupled behaviour of strata and gas in multi-seam mining conditions (Qingdong et al, 2015). The model comprised (i) a fractured gas-interflow zone, (ii) a destressed gas-desorption zone and (iii) a confined gas-adsorption zone. They were characterised based on the characteristics of mining-induced fractures, gas desorption and migration. The lower two zones were the major gas-producing zones during mining, with gas from the lowest zone being the primary source of ventilation methane emissions and the major target of methane emission control. They have also established a method of discriminating the zones and estimating their extent based on the key stratum hypothesis, and verified that it is more reliable than the empirical method used in China (Qingdong et al., 2015). Borowski compared the methane control procedure applied in Poland and Vietnam. To achieve an efficient methane drainage borehole pattern considering U, Y and Z- shaped ventilation systems, they tried to identify the methane desorption zone (Borowski et al., 2018). Zapletal suggested a new method of gas drainage as a solution to dangerous phenomena in the Czech Republic underground coal mines (Zapletal et al., 2017). In Wang's opinion, accurately determining the height of the gasguiding fracture zone in the overlying strata of the goaf is the key to finding the height of the long horizontal borehole in the roof (Wang et al, 2018). Najafi developed a new coal seam methane drainage ability index (CMDI) for pre-drainage techniques in a working mine using a fuzzy rock engineering system (FRES). Their considered seventeen parameters as the main factors affecting the methane drainage from a coal seam (Najafi and Rafiee, 2019). Feng and et al proposed and implemented a method for determining the methane enrichment zone (MEZ) within the zone of interconnected fractures of a longwall coal mine. In their proposed method, the surface directional borehole (SDB) was designed and implemented in a longwall face located in the Sihe Coal Mine of China's Shanxi Province. The trajectory of the SDB varied constantly in the different overlying stratum layers and locations above the mine gob. The data regarding the methane flow rate and concentration obtained from the SDB and the methane concentrations in the upper corner as the longwall face advanced were monitored and obtained simultaneously. The MEZ had been accurately determined in the examined mine. In the MEZ, both the methane flow rate and concentration were found to be the highest despite a slight decrease as the active mining face distance increased. They observed that two zones existed below and above the MEZ, which were referred to as the methane decrease zone (MDZ) and the methane shortage zone (MSZ), respectively. Within the MDZ, both the methane flow rate and concentration displayed gradual decreasing trends as the distance of the mining face advancement increased. Within the MSZ, the methane flow rate and concentration were determined to be lowest among the three zones and also had displayed dramatic fluctuation (Feng et al., 2019). In order to determine the best position at the end of a gas drainage hole, Li et al. put forward a new research method that involves connecting the gas monitoring system in the drainage hole to study the development process of the rock fracture. First of all, they used UDEC software to simulate the collapse characteristics of overburden above a goaf. The simulation results showed that when the working face advances to different distances, the fracture development process of the overlying strata in the horizontal direction of the goaf has four characteristics: the fracture area of the original rock stratum, the fracture channel generation and development area, the fracture channel mature area, and the fracture channel closure area. In the vertical direction of the goaf floor, there are three characteristics of overburden: caving zone, fracture zone, and bending subsidence zone. The results of the field test showed that the data 
law of gas drilling in different layers is consistent with that of numerical simulation Li et al., (2019).

The main objective of this study is to determine the methane desorption zone in the Tabas Parvadeh coal mine. To achieve this goal, the height of a destressed zone is specified and then the drainage drilling pattern is designed using experimental formulas.

\section{Methane desorption areas in the longwall mining method}

A type of methane drainage that has the greatest influence on safety is methane drainage performed during extraction work. This kind of methane drainage is carried out in rock masses de-stressed by longwall mining, and

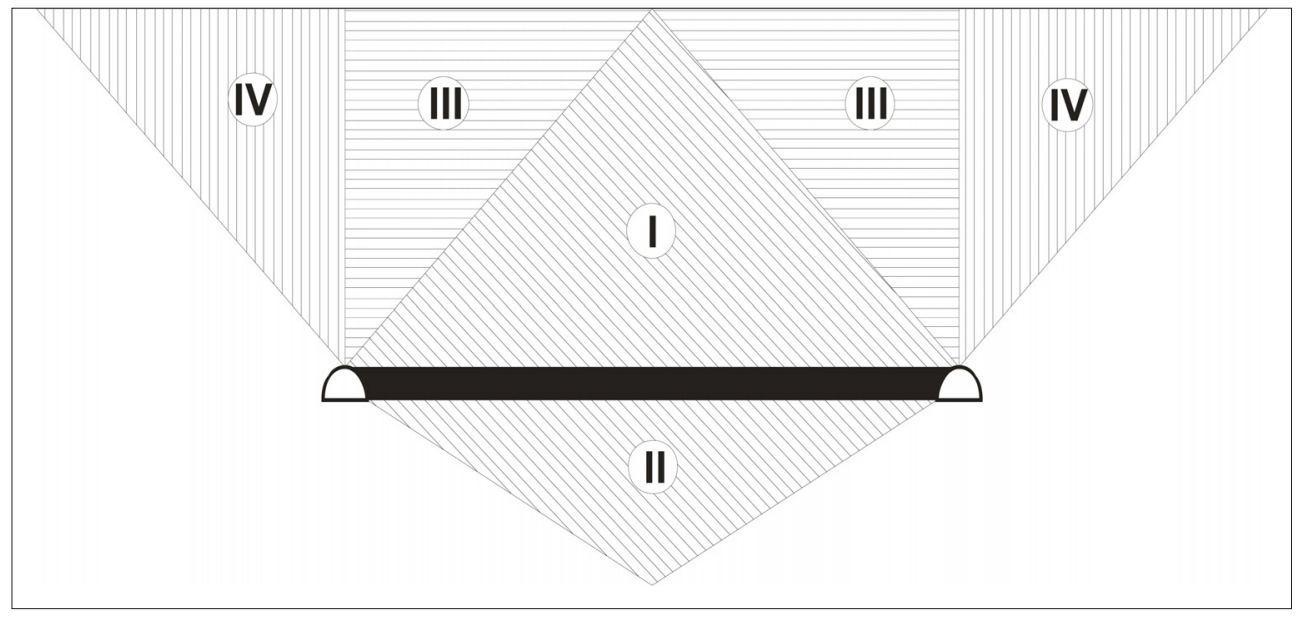

Area I - tensile stresses in the roof strata - desorption and methane flow

Area Il - tensile stresses in the floor strata - desorption and methane flow

Area III - shear stresses - no methane desorption, low free methane flow

Area IV - compressive stresses - no desorption nor methane flow

Figure 2: Stress areas around a longwall panel (Skotniczny., 2013)

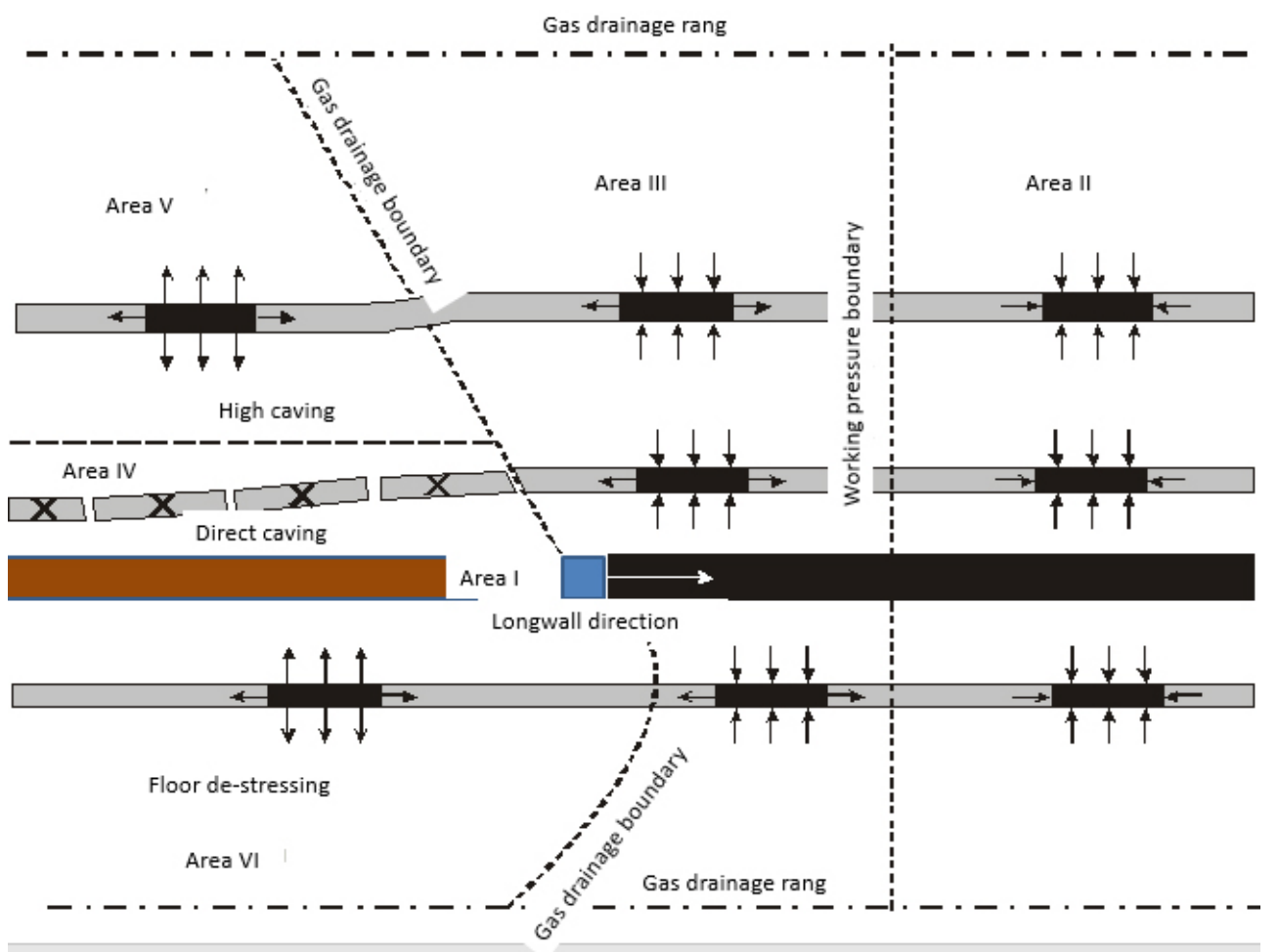

Figure 3: Gas drainage cross-section, parallel to the longwall panel (https://dtek.com/content/files/zbigniew-lubosik.pdf) 


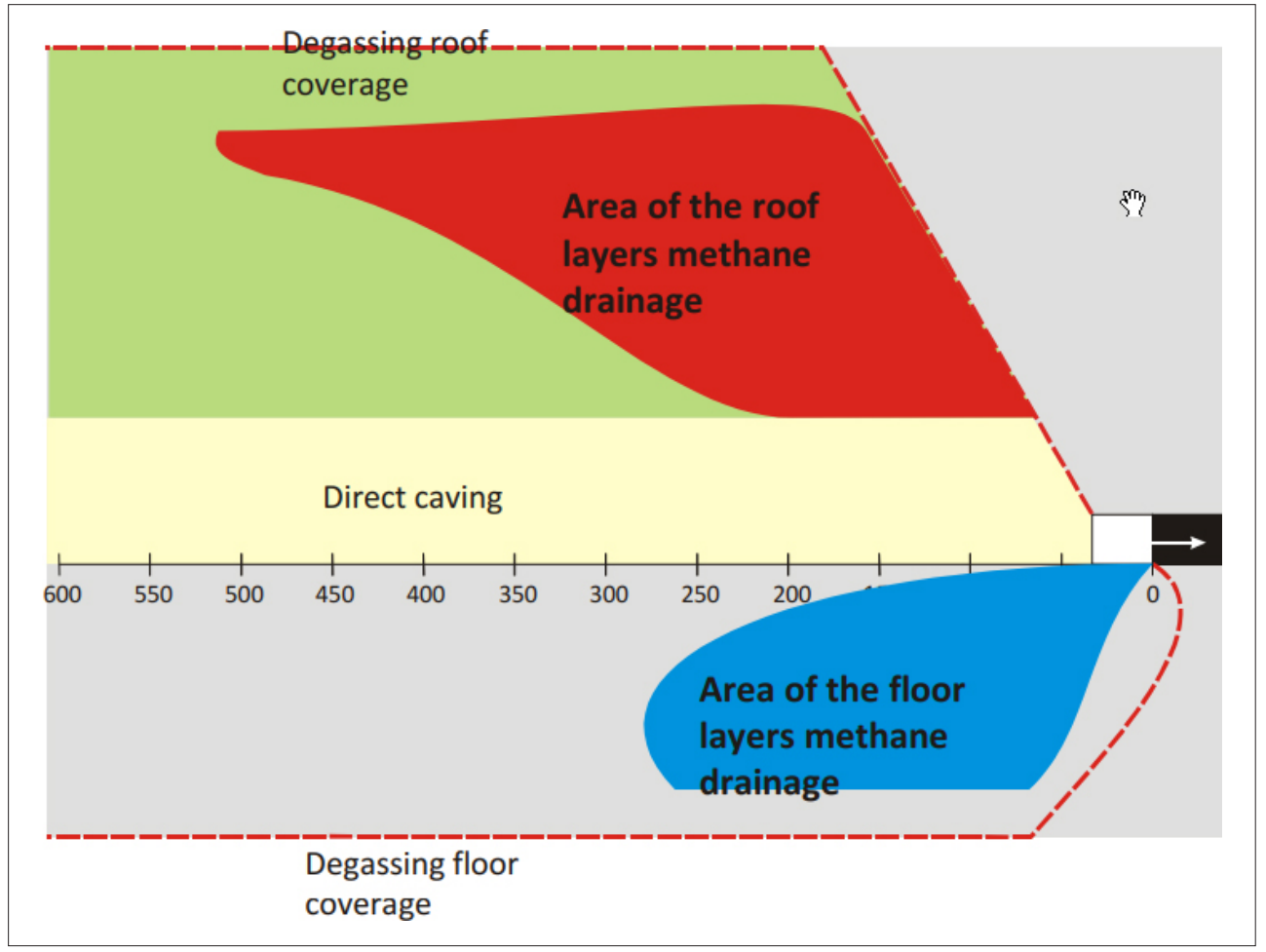

Figure 4: Methane drainage areas in the longwall panel (https://dtek.com/content/files/zbigniew-lubosik.pdf)

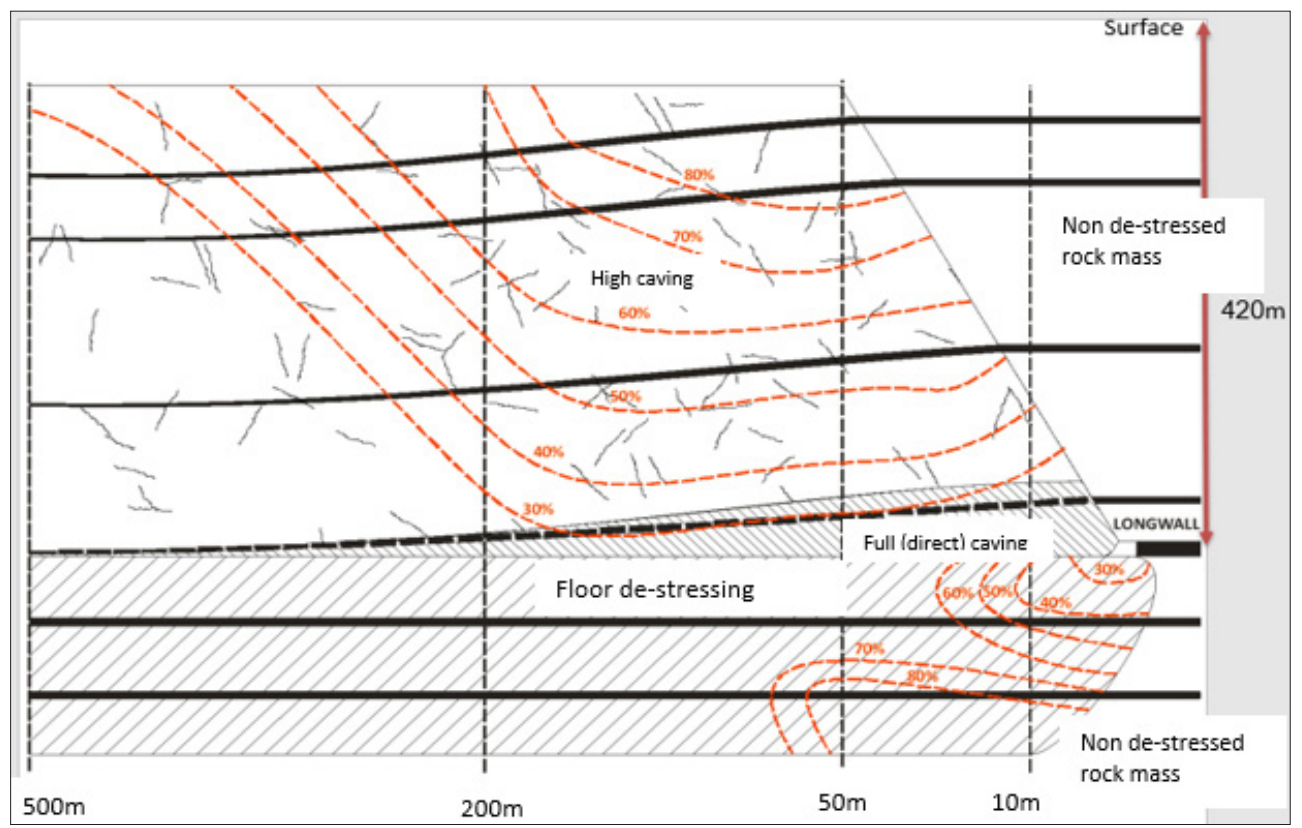

Figure 5: Vertical distribution of methane concentration in the goaf of a longwall face (Krause et al.,2015)

more specifically, the areas of the rock mass that exhibit the occurrence of tensile stresses are shown in Figure 2. A desorption zone is generated as a result of the destressing, in which the methane sorbed by the coal is first released to the fissures and macropores generated by the influence of the aforementioned stresses, and afterwards flows out into the goaf atmosphere. Methane flow from the goaf atmosphere into the workings (longwall face and gallery workings) is determined by the influence of the mine ventilation network on the goaf. The obtained methane drainage efficiency during extraction work, understood as the percentage of contribution of the obtained methane in its overall emission in the longwall environment, which is $10-40 \%$ on average. 
The methane drainage efficiency depends on the following issues:

- geological and mining conditions

- the employed methane drainage technology and its utilization in practice

- the methane drainage network parameters

- the influence of the ventilation network on the longwall goaf, which is of particular importance.

Methane drainage using drainage boreholes is limited exclusively to these areas of the rock mass which exhibit the occurrence of tensile stresses that result in methane desorption. Methane drainage can be performed in a de-stressed zone behind the longwall caving line, both in the roof and floor strata. However, a direct (full) caving zone and a high caving zone have to be distinguished in the roof strata. The direct caving zone encompasses strata deposited directly above the mined coal bed up to a height equaling, on average, five times the mining thickness. After a short time (between several to dozens of hours), a near-complete release of the methane sorbed by these coalbeds occurs, while its flowing in the goaf depends on the influence of the depression generated by the ventilation network. Generally, the presence of methane drainage holes subjected to depression has no influence on the flows in this zone. In some cases, under satisfactory goaf isolation airtightness, when using ventilation systems with air off take along the goaf, drainage holes with direct contact in the direct caving may be used for methane drainage, but this essentially constitutes methane intake from the goaf. Methane drainage areas in longwall mining are shown in Figures 3 and 4.

According to Figure 3, the description of each area is as follow:

Area I - Longwall operation, free methane inflow from the sidewall, roof strata, floor strata and goaf.

Area II - In a non-de-stressed rock mass, tensile stress occurrence, no methane desorption.

Area III - In a partially de-stressed rock mass, shear and compressive stress occurrence, as well as tensile stress occurrence parallel to the bedding; limited methane desorption.

Area IV - Direct caving, total coal bed destruction, only free methane is present.

Area V - In a de-stressed rock mass, tensile stress occurrence, intense methane desorption.

Area VI - In a de-stressed rock mass, tensile stress occurrence, intense methane desorption.

Coal exploitation destroys the structure of the overlying and underlying coal seams, releasing a large volume of methane from the exploited seam, the remaining part comes from neighboring seams. The distribution of methane emission behind the longwall mining is shown in Figures $\mathbf{4}$ and 5. Figure $\mathbf{5}$ shows a presumed vertical distribution of methane concentration in the goaf of a longwall face (a cross-section along the panel length).
Methane drainage in a rock-mass is the most efficient and effective method for preventing methane hazards as it reduces the frequency of methane inflows into working areas and prevents or reduces incidents such as outflows, methane and rock outbursts, etc. The most efficient method is draining methane from a rock-mass and goafs of longwalls and pumping it to the surface through pipelines, using the negative pressure of drainage station pumps. Although this methane drainage method ensures the desired parameters regarding mine ventilation, it creates specific requirements concerning development in methane-bearing coal seams.

For methane drainage in adjacent (overlying and underlying) coal seams, it is required to determine the boundaries of the desorption zone created by the extraction of the longwall face. Drainage boreholes should be positioned in the destressed zone without overlapping with the goaf area. Accurate calculations of the methane drainage boreholes angles are achieved using the method described and presented in Figure 6.

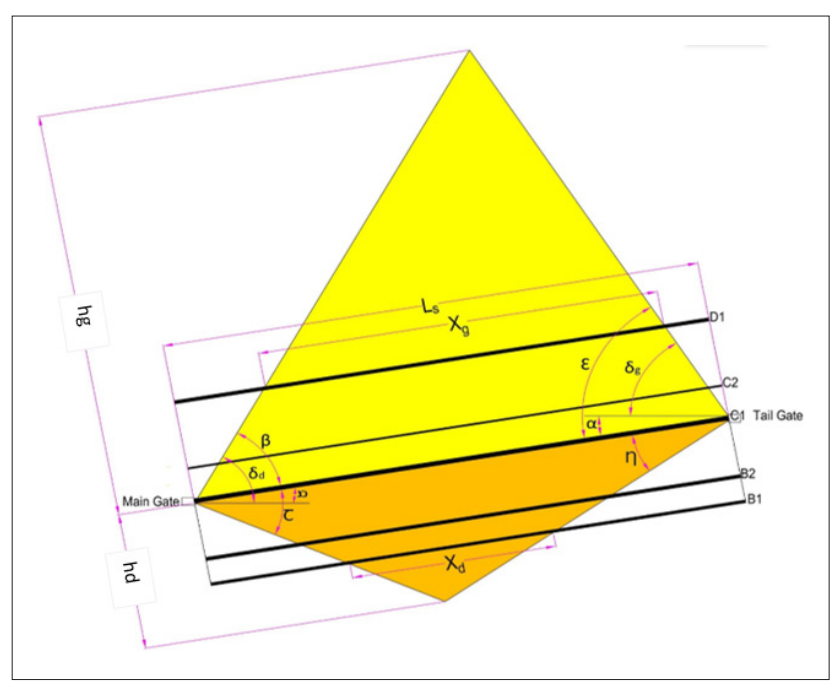

Figure 6: Desorption zone cross-section, perpendicular to the longwall panel

The angles in Figure 6 refer to boreholes drilled in a direction parallel to the longwall face. Their inclination is approximately equal to the desorption angle. In the event that the boreholes are inclined relative to the longwall face, the values need to be adjusted accordingly. If boreholes are drilled from a parallel heading, it is necessary to take into account the width of the pillars separating the heading and to ensure that most of borehole length remains in the destressed zone.

The length of the borehole is determined by geological and lithological conditions of the area, particularly by the position of the underlying and overlying seams. The objective is to extend the boreholes to all coal seams in the destressed zone, as far as it is technically possible (Szlazak et al, 2014; Szlazak et al, 2014; Szlazak et al, 2016). 
Using the parameters from Figure 6, the height of the desorption zone can be calculated with the following formulas (Szlazak et al, 2014):

$$
\begin{aligned}
& \mathrm{h}_{\mathrm{g}}=\mathrm{L}_{\mathrm{s}} \cdot \frac{\operatorname{tg} \beta \cdot \operatorname{tg} \varepsilon}{\operatorname{tg} \beta+\operatorname{tg} \varepsilon}=\frac{\mathrm{L}_{\mathrm{s}}}{\mathrm{G}_{\mathrm{g}}} \\
& \mathrm{h}_{\mathrm{d}}=\mathrm{L}_{\mathrm{s}} \cdot \frac{\operatorname{tg} \eta \cdot \operatorname{tg} \tau}{\operatorname{tg} \eta+\operatorname{tg} \tau}=\frac{\mathrm{L}_{\mathrm{s}}}{\mathrm{G}_{\mathrm{d}}}
\end{aligned}
$$

Desorption zone angles for the Tail gate and the Main gate in the roof:

$$
\begin{aligned}
& \beta=\delta_{\mathrm{d}}-\alpha \\
& \varepsilon=\delta_{\mathrm{g}}+\alpha
\end{aligned}
$$

Desorption zone angles for the Tail gate and the Main gate in the floor:

$$
\begin{aligned}
\tau & =\frac{\beta}{2} \\
\eta & =\frac{\varepsilon}{2}
\end{aligned}
$$

\section{Where:}

$L s$ - is the longwall panel width (m);

$\alpha-$ is the dip of a mined coal seam (deg);

$h g$ - is the desorption zone in roof layers (m);

$h d-$ is the desorption zone in floor layers (m);

$\beta-$ is the desorption zone angle in the roof of the Main gate (deg);

$\tau-$ is the desorption zone angle in the floor of the Main gate (deg);

$\varepsilon \quad-$ is the desorption zone angle in the roof of the Tail gate (deg);

Table 1: Coefficient values $\left(G_{q}, G_{d}\right)$ (Krause et al., 2014)

\begin{tabular}{|l|c|c|c|c|c|c|c|c|c|c|}
\hline Coal seam dip (deg) & $0-5$ & $6-10$ & $11-15$ & $16-20$ & $21-25$ & $26-30$ & $31-35$ & $36-40$ & $41-45$ & $46-50$ \\
\hline$G_{g}$ & 1.46 & 1.48 & 1.51 & 1.54 & 1.58 & 1.62 & 1.68 & 1.74 & 1.87 & 2.05 \\
\hline$G_{d}$ & 3.93 & 3.98 & 4.04 & 4.10 & 4.18 & 4.25 & 4.37 & 4.51 & 4.8 & 5.18 \\
\hline
\end{tabular}

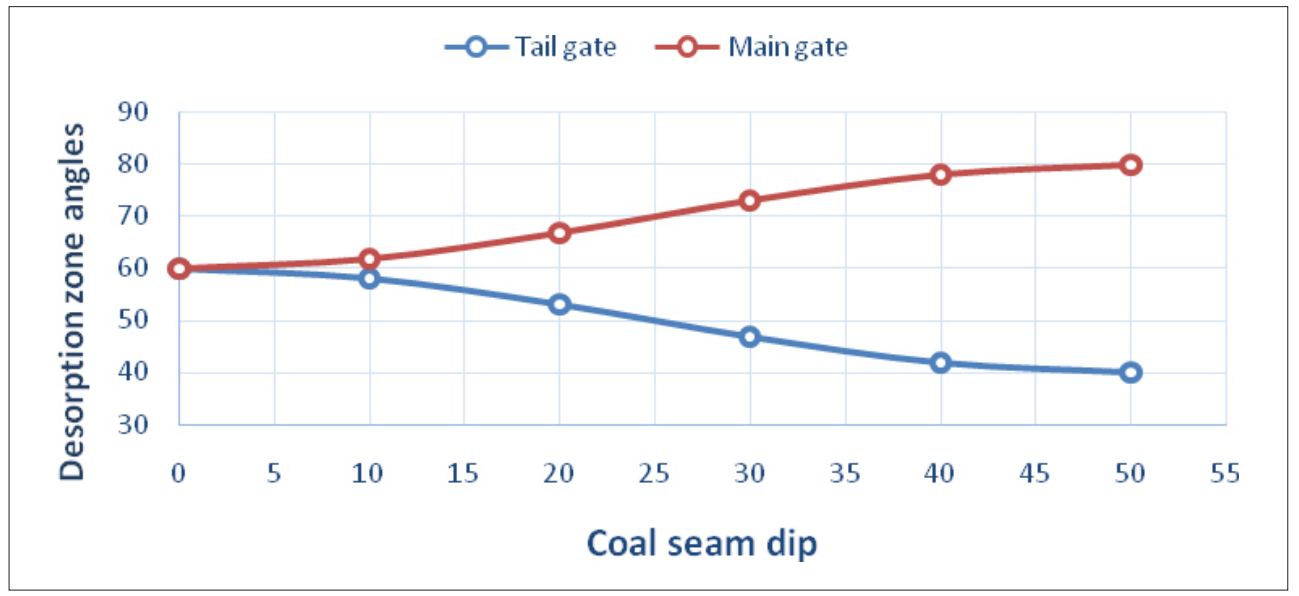

Figure 7: Relation between the coal seam inclination angle and desorption angles (in roof strata)

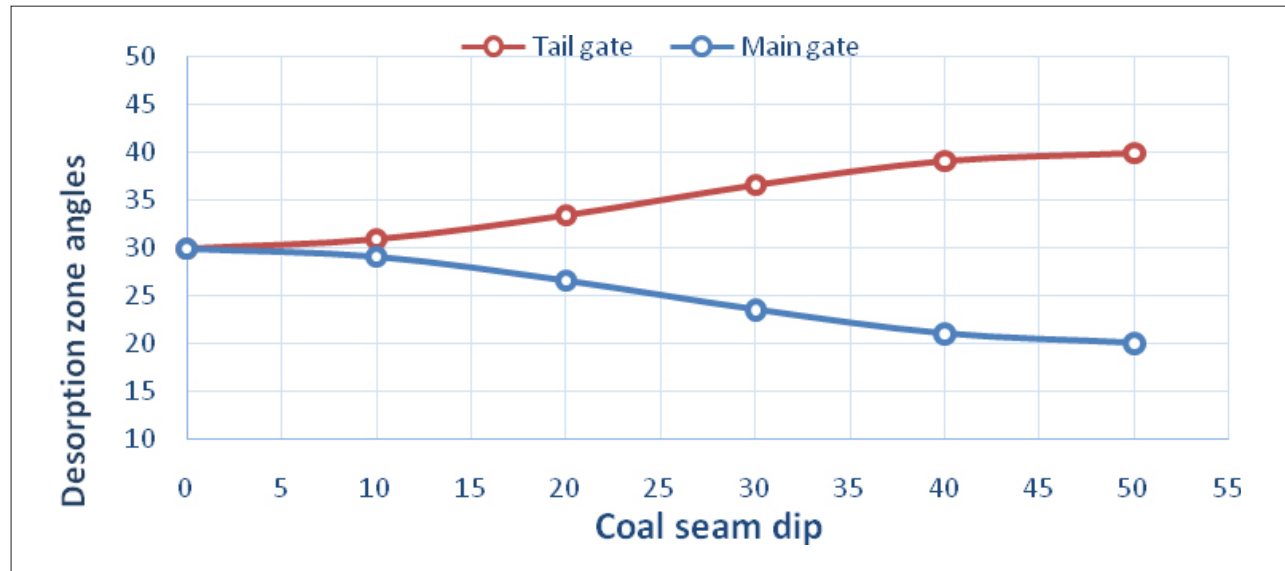

Figure 8: Relation between the coal seam inclination angle and desorption angles (in floor strata) 
$\eta$ - is the desorption zone angle in the floor of the Tail gate (deg);

$a-$ is the distance from the extraction work (roof) (m);

$b-$ is the distance from the extraction work (floor) (m);

$G g$ and $G d$ - constant coefficients that can be determined based on Table 1.
The relations between the coal seam dip and desorption angles in the roof and floor strata are shown in Figures 7 and 8 . The angles of desorption of the floor and roof layer depend on the angle of inclination of the coal seam (the angles of desorption are related to the horizontal plane).

Coal seam width in the desorption zone:

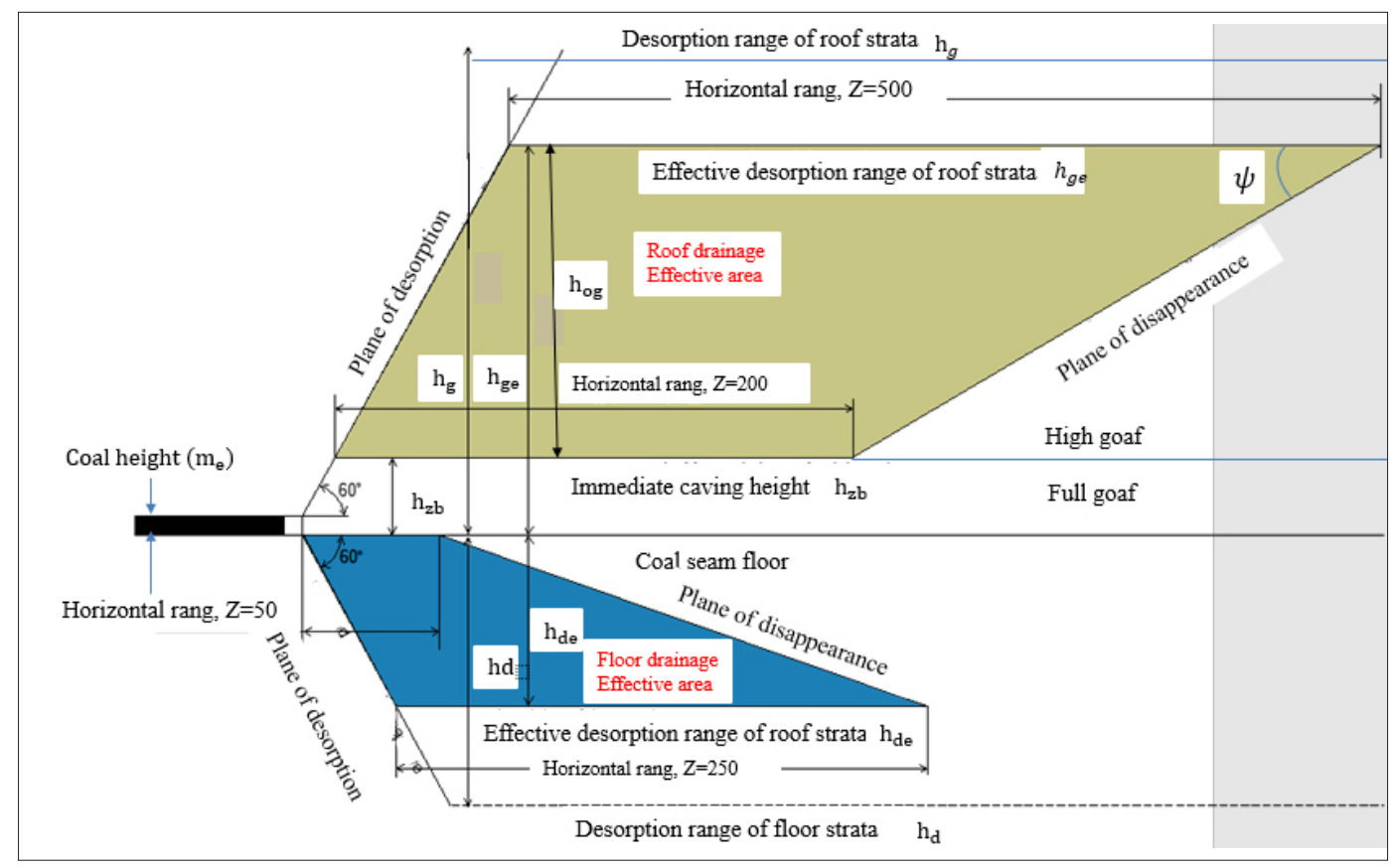

Figure 9: Methane desorption zone in longwall panel (side view) (Krause et al.,2015)

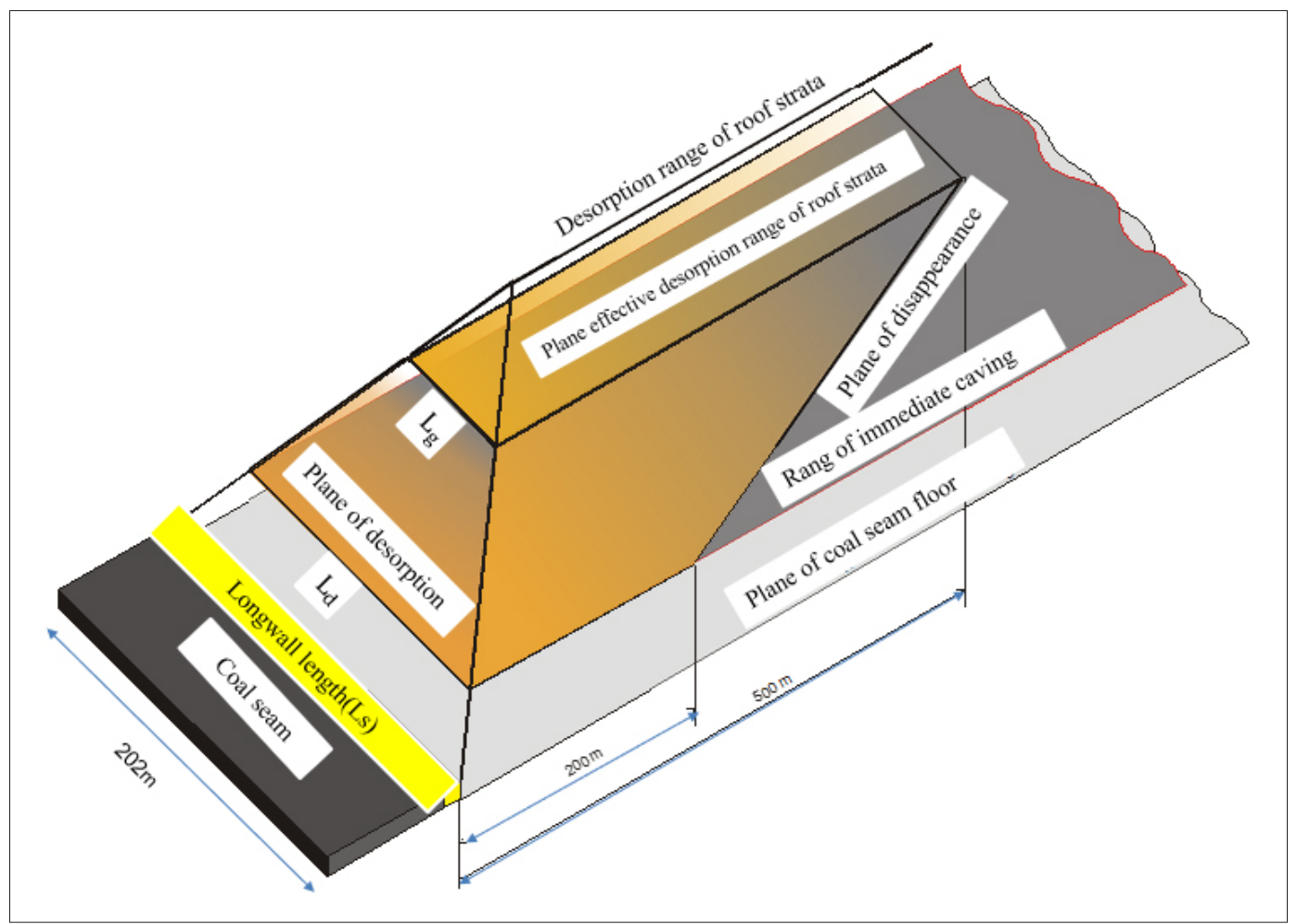

Figure 10: Methane desorption zone in longwall panel (Top view) (Krause et al.,2015) 


$$
\begin{aligned}
& X_{g}=L_{S}-a G_{g} \\
& X_{d}=L_{S}-b G_{d}
\end{aligned}
$$

Figures 9 and 10 have been used to calculate the boundary of the drainage area along the face advancement.

The length of the longwall has the biggest impact on the volume of the released deposit over and under the

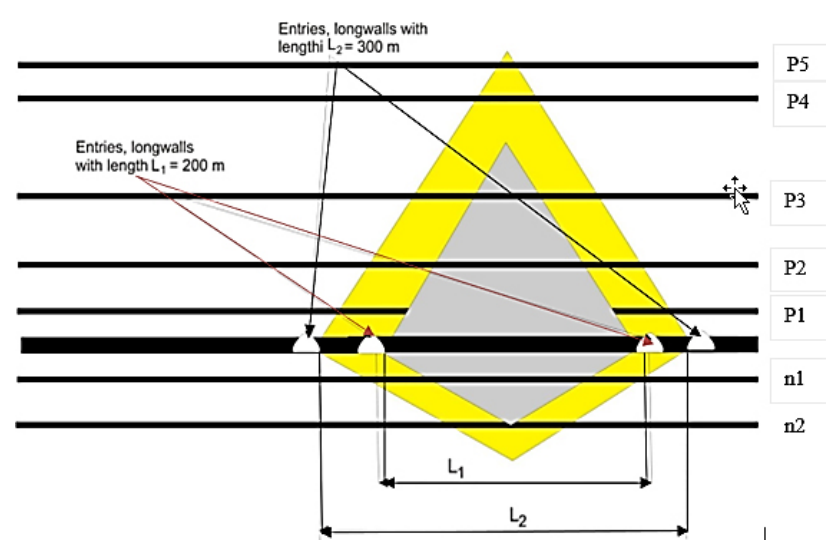

Figure 11: Length effect of longwall on methane drainage desorption zone height (Krause et al., 2014) exploited coal panel and, in consequence, on the volume of released methane to the environment of the longwall's gob. The empirical interrelations enable the calculation of the ranges of the releases: $h_{d}$ and $h_{g}$ according to the parameters Ls and $\alpha$ as shown in Figure 12 (Krause et al., 2014). An increase of the output concentration due to an increase of the longwall length substantially affects the quantity of the methane release into the environment.

Together with an increase of the longwall length from L1 to L2 (see Figure 11) there is an increase of the crosssection through the desorption zone and, in consequence, the volume of the deposit over and under the exploited coal panel also increases. Increasing the longwall length from L1 to L2 results in an increase in the cross-section through the deposit, which has a direct impact on the volume of the deposit being degasified adjacent to the longwall and on the volume of released methane. For the longwall length L1, the exploitation release reaches up to the overlaying seams p1, p2 and p3, however for the length $\mathrm{L} 2$, the range of the release reaches up to the seams P1, P2, P3, P4 and P5. For the longwall length L1 the exploitation release reaches (degasify) the underlying seam $n 1$ and when increasing longwall length up to $\mathrm{L} 2$, it reaches seams $\mathrm{n} 1$ and $\mathrm{n} 2$. The relation between width and inclination of longwall with desorption zone height in the roof and floor layer is shown in Figures 13 and 14.

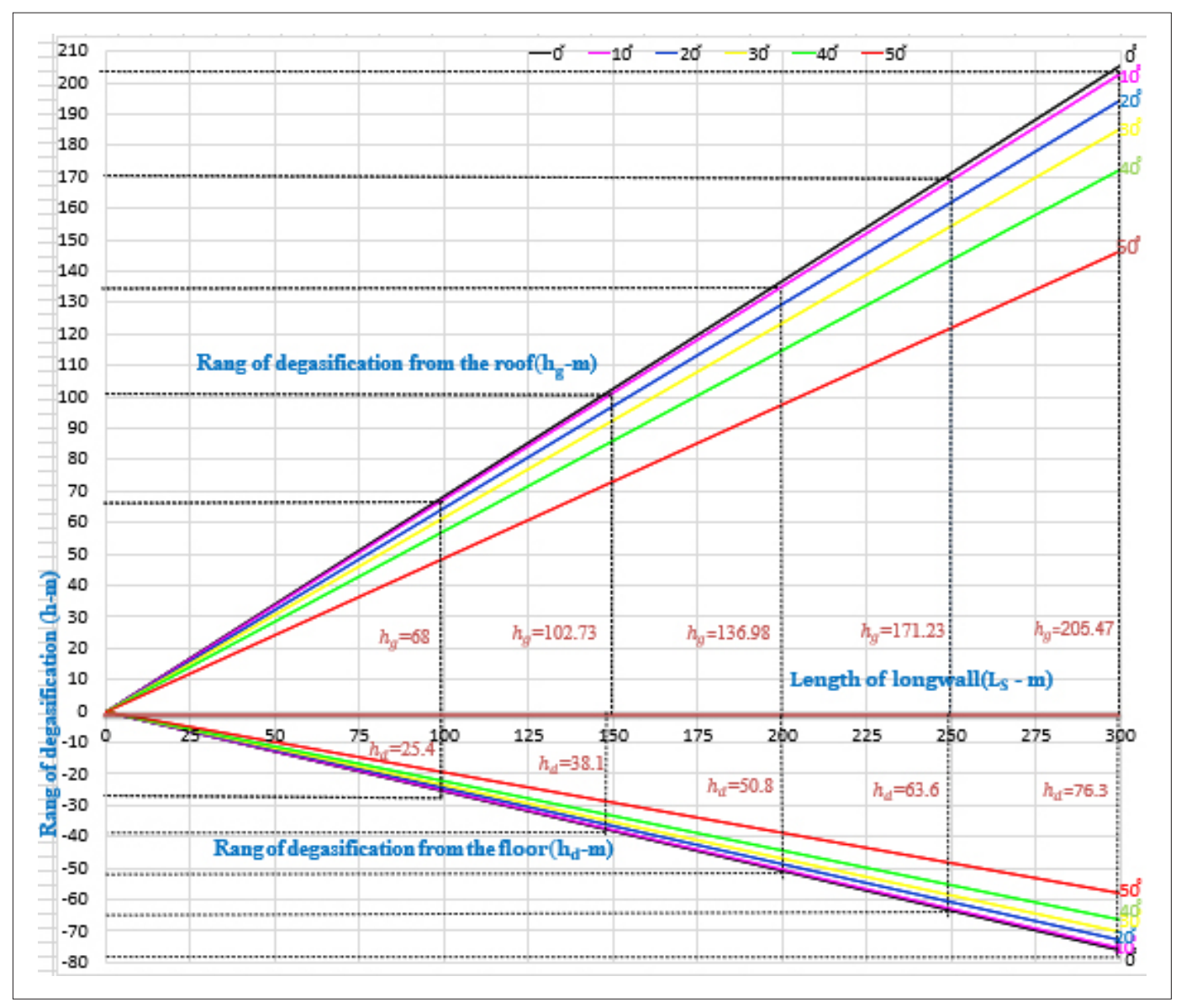

Figure 12: Range of degasification of the overmined and undermined seams depending on longwall length and its inclination (Krause et al., 2014) 


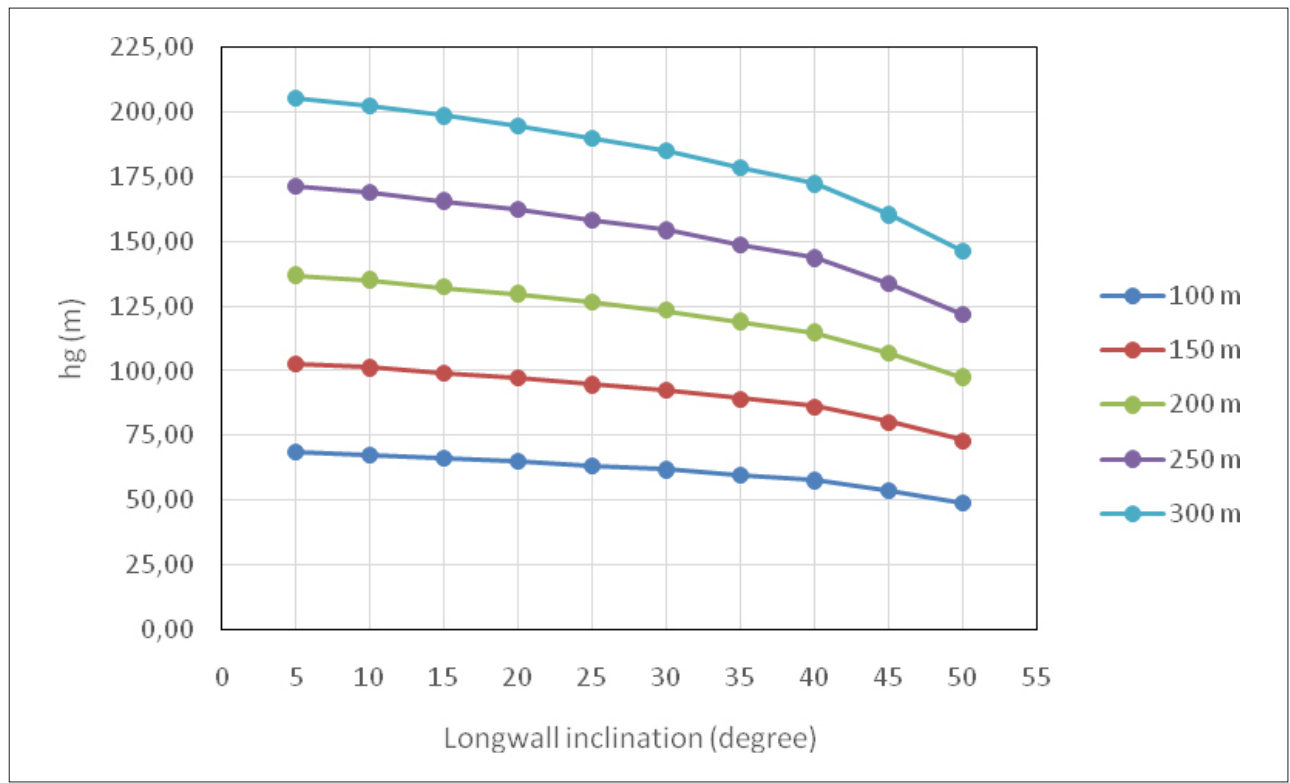

Figure 13: Relation between width and inclination of longwall with height desorption zone in the roof layer

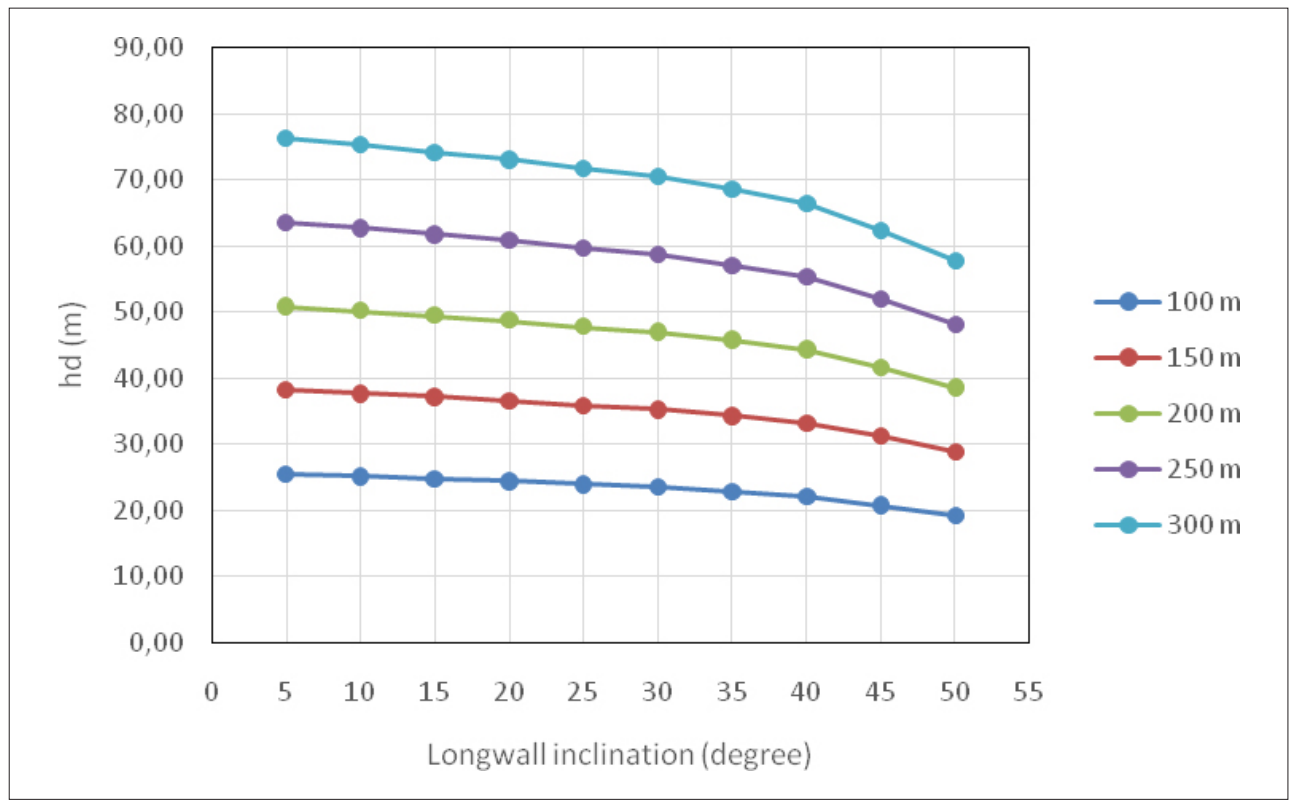

Figure 14: Relation between width and inclination of the longwall with a height desorption zone in the floor layer

\section{Case Study}

The Tabas coal mine is located $75 \mathrm{~km}$ away from Tabas city (see Figure 15). The mine area is about 4 $\mathrm{km}^{2}$, with approximately 34 million tons of coal reserves. Five main coal seams have been explored (B1, B2, C1, C2 and D) at the coal deposit and currently C1 is being worked (see Figure 16). The side view of a typical face line is shown in Figure 14. To date, seven excavation panels have been worked out and the E4 panel is characterized as the gassiest panel of all seven panels. A Methane Drainage System (MDS) has been started for gas extraction from the E3 Panel. Tabas coal seam gas content is around $16 \mathrm{~m}^{3} /$ ton (see Table 2). These also emit high levels of methane. The Tabas coal mine is now experiencing gas outbursts in development headings.

\section{Desorption zone for the methane drainage in $\mathrm{E}_{4}$ panel}

When draining methane from adjacent seams, it is essential to specify the zone of desorption brought on by longwall exploitation. Drainage boreholes should be located such that they are in the stress relief zone. After 
The upper methane drainage plane width:

$$
\mathrm{L}_{\mathrm{g}}=\mathrm{L}_{\mathrm{s}}-0.8 \mathrm{~h}_{\mathrm{g}} \cdot \mathrm{G}_{\mathrm{g}}
$$

The methane drainage area lateral surface:

$$
\mathrm{S}_{\mathrm{og}}=\frac{\left(\mathrm{L}_{\mathrm{g}}+\mathrm{L}_{\mathrm{d}}\right) \mathrm{h}_{\mathrm{og}}}{2}
$$
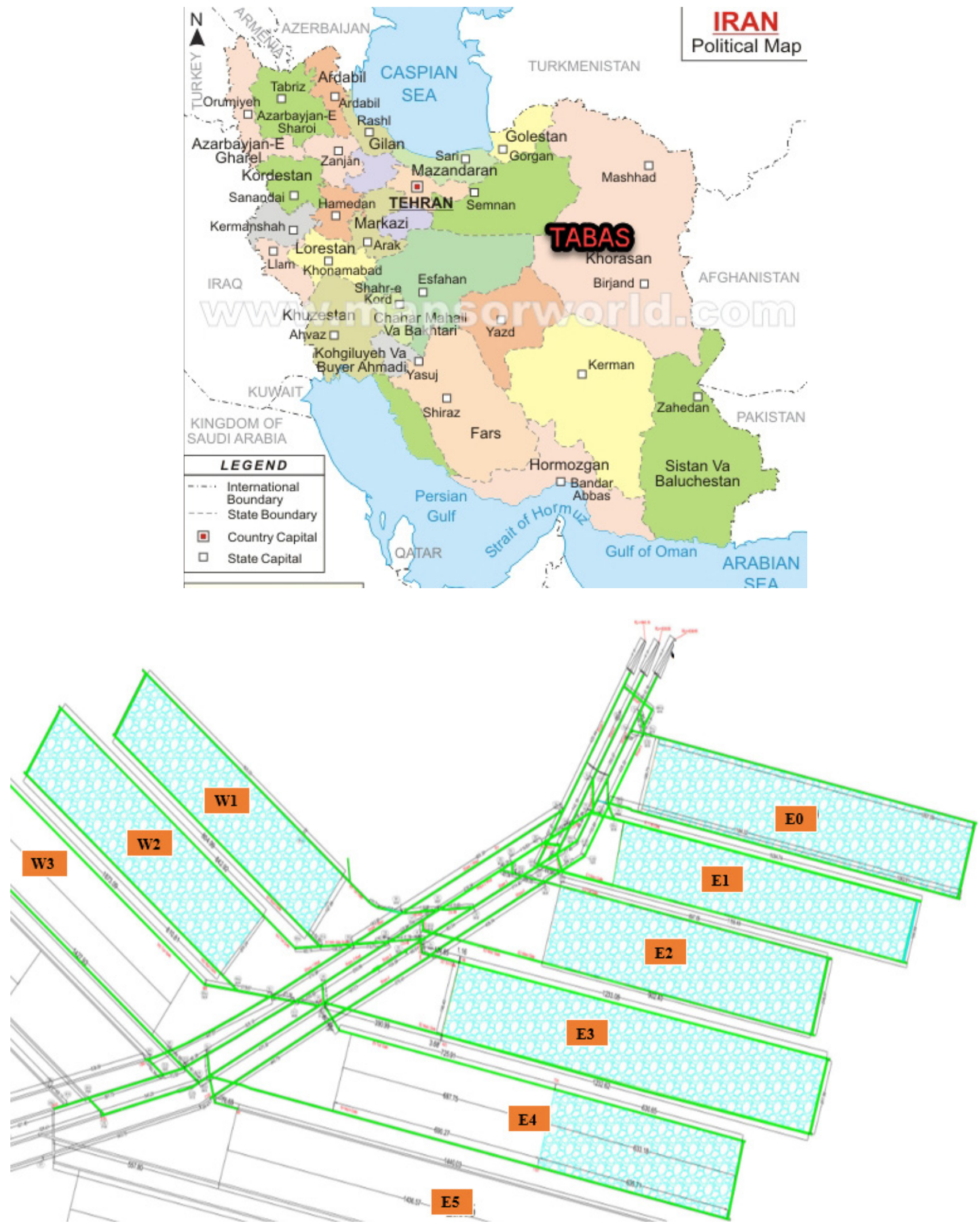

Figure 15: Tabas Parvadeh No1 coal mine (2020)

Rudarsko-geološko-naftni zbornik i autori (The Mining-Geology-Petroleum Engineering Bulletin and the authors) (C, 2020, pp. 61-75, DOI: 10.17794/rgn.2021.1.6 


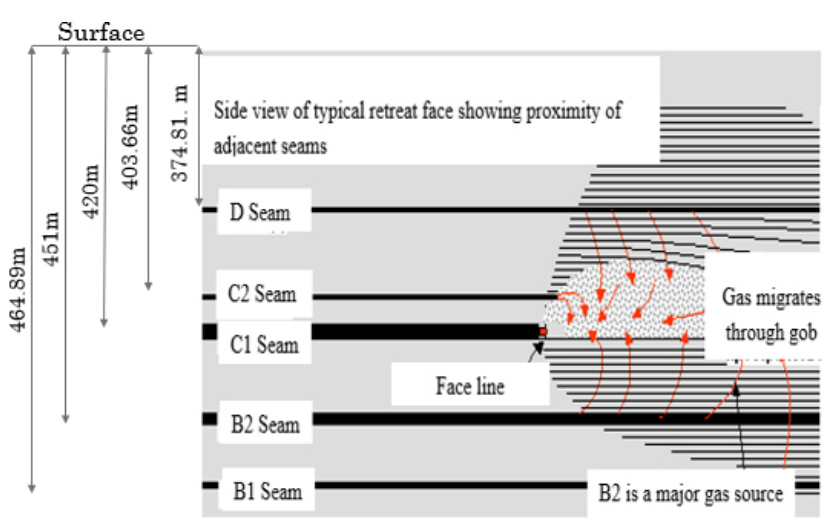

Figure 16: Tabas No1 mine coal seams (Anon, 2005)

Table 2: Average coal seam gas content in the Tabas coal mine (Anon, 2005)

\begin{tabular}{|l|c|c|}
\hline $\begin{array}{l}\text { Seam Depth } \\
(\mathbf{m})\end{array}$ & $\begin{array}{c}\text { B1 \& B2 seams } \\
\left(\mathbf{m}^{3} / \text { ton }\right)\end{array}$ & $\begin{array}{c}\text { C1 seam } \\
\left(\mathbf{m}^{3} / \text { ton }\right)\end{array}$ \\
\hline 100 & 10.4 & 10.2 \\
\hline 200 & 15.5 & 15.4 \\
\hline 300 & 18 & 17.1 \\
\hline 400 & 19.9 & 17.8 \\
\hline 500 & 20.3 & 19.4 \\
\hline 600 & 20.7 & 19.8 \\
\hline 700 & 21 & 20 \\
\hline
\end{tabular}

identification of the length and inclination of the E4 panel, the desorption zone is calculated using the abovementioned Equations (1-8) to maximize the methane drainage drilling efficiency. The base on the angles and parameters are identified in Table $\mathbf{3}$, and the desorption zone was designed and shown in Figure 17.

The parameters illustrated in Figures 9 and $\mathbf{1 0}$ can be calculated using the following equations. Considering the figures above, the volume of drained gas can be calculated. The results of the calculations are shown in Table 4.

The immediate caving height (also lower methane drainage plane height for roof strata):

$$
h_{z b}=5 m_{e}
$$

The desorption range of the roof strata:

$$
\mathrm{h}_{\mathrm{g}}=\frac{\mathrm{L}_{\mathrm{s}}}{\mathrm{G}_{\mathrm{g}}}
$$

The effective desorption range of roof strata:

$$
\mathrm{h}_{\mathrm{ge}}=0.8 \mathrm{~h}_{\mathrm{g}}
$$

The methane drainage area height:

$$
\mathrm{h}_{\mathrm{og}}=\mathrm{h}_{\mathrm{ge}}-\mathrm{h}_{\mathrm{zb}}=0.8 \mathrm{~h}_{\mathrm{g}}-5 \mathrm{~m}_{\mathrm{e}}
$$

Table 3: Determining methane desorption zone parameters in the $\mathrm{E}_{4}$ longwall panel

\begin{tabular}{|l|l|c|c|}
\hline$L_{s}$ & Longwall length & 202 & $\mathrm{~m}$ \\
\hline$\alpha$ & $\begin{array}{l}\text { Dip angle of the mined coal } \\
\text { seam }\end{array}$ & 10 & $\mathrm{deg}$ \\
\hline$h_{g}$ & $\begin{array}{l}\text { Desorption zone in the roof } \\
\text { layers (Height) }\end{array}$ & 136.4 & $\mathrm{~m}$ \\
\hline$h_{d}$ & $\begin{array}{l}\text { Desorption zone in the floor } \\
\text { layers (Height) }\end{array}$ & 50.7 & $\mathrm{~m}$ \\
\hline$\beta$ & $\begin{array}{l}\text { Desorption zone angle } \\
\text { in the roof main gate }\end{array}$ & 51.9 & $\mathrm{deg}$ \\
\hline$\tau$ & $\begin{array}{l}\text { Desorption zone angle } \\
\text { in the floor main gate }\end{array}$ & 26 & $\mathrm{deg}$ \\
\hline$\varepsilon$ & $\begin{array}{l}\text { Desorption zone angle } \\
\text { in the roof tail gate }\end{array}$ & 68.1 & $\mathrm{deg}$ \\
\hline$\eta$ & $\begin{array}{l}\text { Desorption zone angle } \\
\text { in the floor tail gate }\end{array}$ & 34.1 & $\mathrm{deg}$ \\
\hline$X_{g}$ & $\begin{array}{l}\text { Coal bed width in the roof } \\
\text { desorption zone }\end{array}$ & 142.59 & $\mathrm{~m}$ \\
\hline$X_{d}$ & $\begin{array}{l}\text { Coal bed width in the floor } \\
\text { desorption zone }\end{array}$ & 70.73 & $\mathrm{~m}$ \\
\hline$G_{g}$ & Coefficient value & 1.48 & From table 1 \\
\hline$G_{d}$ & Coefficient value & 3.98 & From table 1 \\
\hline
\end{tabular}

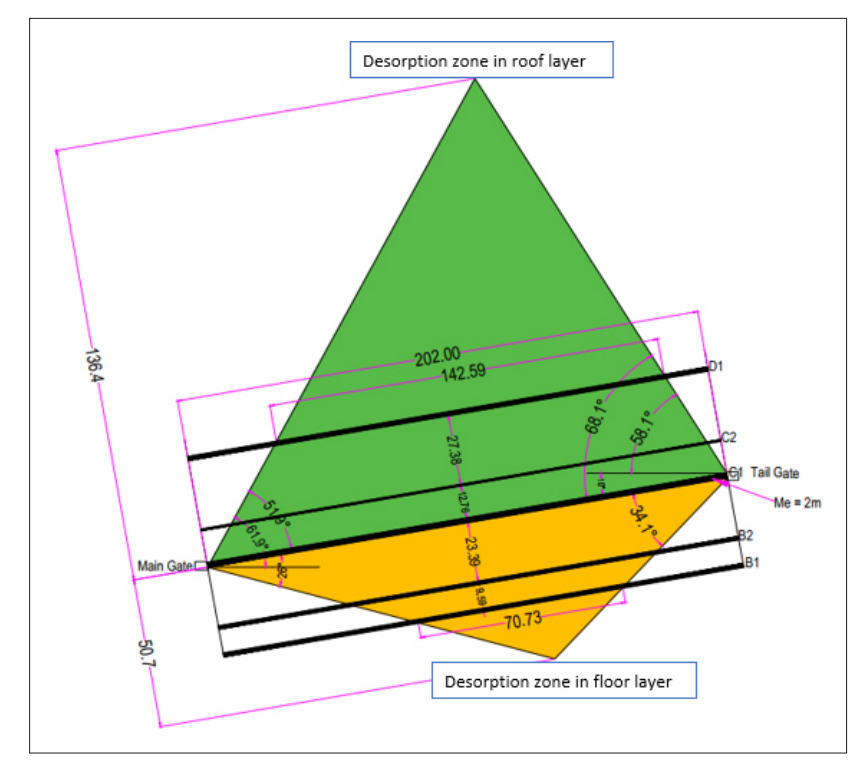

Figure 17: Methane desorption zone in the E4 longwall panel

The desorption range of the floor strata:

$$
\mathrm{h}_{\mathrm{d}}=\frac{\mathrm{L}_{\mathrm{s}}}{\mathrm{G}_{\mathrm{d}}}
$$

The effective desorption range of the floor strata:

$$
\mathrm{h}_{\mathrm{de}}=0.85 \mathrm{~h}_{\mathrm{d}}
$$

The lower methane drainage plane width:

$$
\mathrm{L}_{\mathrm{d}}=\mathrm{L}_{\mathrm{s}}-\mathrm{h}_{\mathrm{zb}} \cdot \mathrm{G}_{\mathrm{g}}
$$


The methane drainage volume:

$$
\mathrm{V}_{\mathrm{og}}=\mathrm{S}_{\mathrm{og}}\left\{\frac{\mathrm{h}_{\mathrm{og}}}{3.462}+\left(200-\frac{\mathrm{h}_{\mathrm{og}}}{1.732}\right)+\left[\frac{500-\left(200-\frac{\mathrm{h}_{\mathrm{og}}}{1.732}\right)}{2}\right]\right\}
$$

Table 4: Determining methane desorption zone parameters in the E4 longwall panel (side and top view)

\begin{tabular}{|l|l|c|c|}
\hline $\mathrm{L}_{\mathrm{s}}$ & Longwall panel width & 202 & $\mathrm{~m}$ \\
\hline$\alpha$ & $\begin{array}{l}\text { Sloping angle of the mined coal } \\
\text { seam }\end{array}$ & 10 & $\mathrm{deg}$ \\
\hline $\mathrm{m}_{\mathrm{e}}$ & Mining height & 2 & $\mathrm{~m}$ \\
\hline $\mathrm{h}_{\mathrm{g}}$ & Desorption zone in the roof layers & 136.4 & $\mathrm{~m}$ \\
\hline $\mathrm{h}_{\mathrm{d}}$ & Desorption zone in the floor layers & 50.7 & $\mathrm{~m}$ \\
\hline $\mathrm{h}_{\mathrm{zb}}$ & Immediate caving height & 10 & $\mathrm{~m}$ \\
\hline $\mathrm{h}_{\mathrm{ge}}$ & $\begin{array}{l}\text { Effective desorption range } \\
\text { of the roof strata }\end{array}$ & 109.12 & $\mathrm{~m}$ \\
\hline $\mathrm{h}_{\mathrm{og}}$ & Methane drainage area height & 99.12 & $\mathrm{~m}$ \\
\hline $\mathrm{h}_{\mathrm{de}}$ & $\begin{array}{l}\text { Effective desorption range } \\
\text { of the floor strata }\end{array}$ & 43.09 & $\mathrm{deg}$ \\
\hline $\mathrm{L}_{\mathrm{d}}$ & Lower methane drainage plane width & 187.2 & $\mathrm{~m}$ \\
\hline $\mathrm{L}_{\mathrm{g}}$ & Upper methane drainage plane width & 40.5 & $\mathrm{~m}$ \\
\hline $\mathrm{S}_{\mathrm{og}}$ & $\begin{array}{l}\text { Methane drainage area lateral } \\
\text { surface }\end{array}$ & 11284.81 & $\mathrm{~m}^{2}$ \\
\hline $\mathrm{V}_{\mathrm{og}}$ & Methane drainage volume & 3948667.86 & $\mathrm{~m}^{3}$ \\
\hline $\mathrm{tg}_{\Psi}$ & Plane of decay rising course & 15.48 & $\mathrm{deg}$ \\
\hline $\mathrm{G}_{\mathrm{g}}$ & Coefficient value & 1.48 & - \\
\hline $\mathrm{G}_{\mathrm{d}}$ & Coefficient value & 3.98 & - \\
\hline
\end{tabular}

The plane of decay rising course:

$$
\operatorname{tg} \psi=\frac{\mathrm{h}_{\mathrm{og}}}{\left[500-\left(200-\frac{\mathrm{h}_{\mathrm{og}}}{1.732}\right)\right]}
$$

Where:

$L s$ - is the longwall panel width (m);

$\alpha \quad$ is the sloping angle of a mined coal seam (deg);

$m e$ - is the mining height ( $\mathrm{m})$;

$h_{d} \quad$ - is the desorption zone in floor layers (m);

$h_{g} \quad$ - is the desorption zone in roof layers;

$h_{z b}$ - is the immediate caving height (m);

$h_{g e}-$ is the effective desorption range of roof strata (m);

$h_{o g}-$ is the methane drainage area height (m);

$h_{d e}-$ is the effective desorption range of floor strata (m);

$L_{d} \quad$-is the lower methane drainage plane width (m);

$L_{g} \quad$ - is the upper methane drainage plane width (m);

$S_{o g}^{g}$-is the methane drainage area lateral surface $\left(\mathrm{m}^{2}\right)$;

$V_{o g}-$ is the methane drainage volume $\left(\mathrm{m}^{3}\right)$;

$\operatorname{tg} \psi$ - is the plane of decay rising course (deg);

$G g$ and $G d$ - constant coefficients that can be determined based on Table 1 .

Once the methane desorption zone has been determined, the methane drainage drilling pattern can be identified. The optimal range of drainage orifice open-

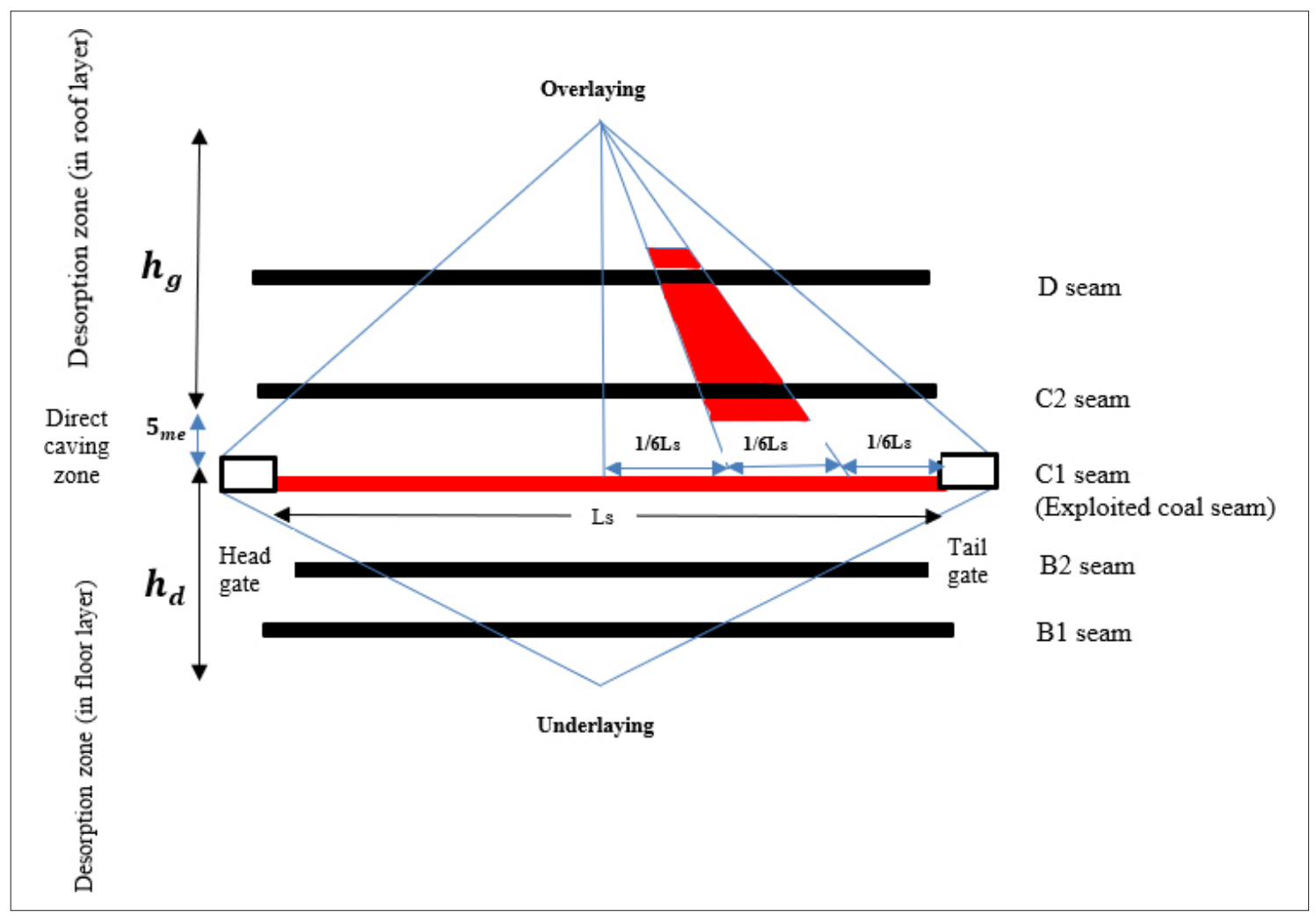

Figure 18: Optimal area for drilling methane drainage borehole 


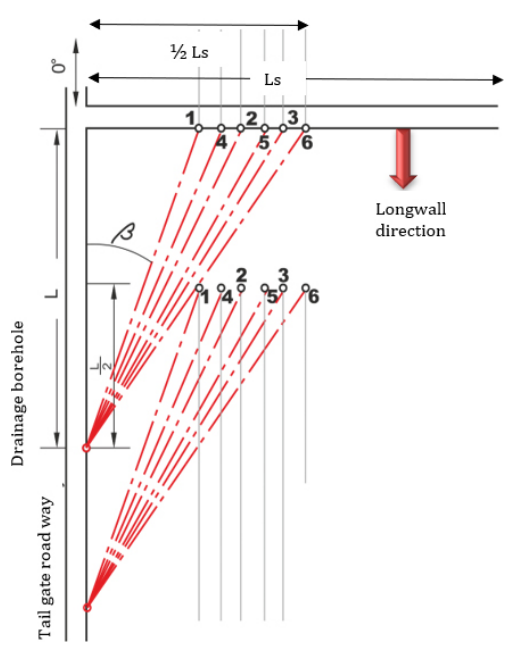

a:Top View

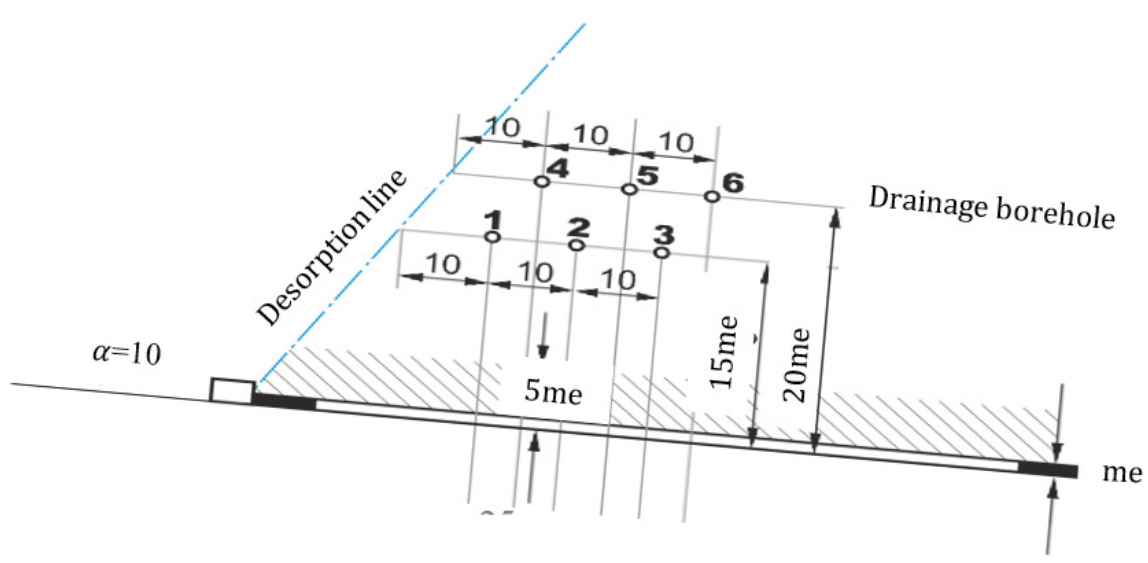

b: Side view

Figure 19: Methane drainage borehole in the desorption zone for the E4 longwall panel
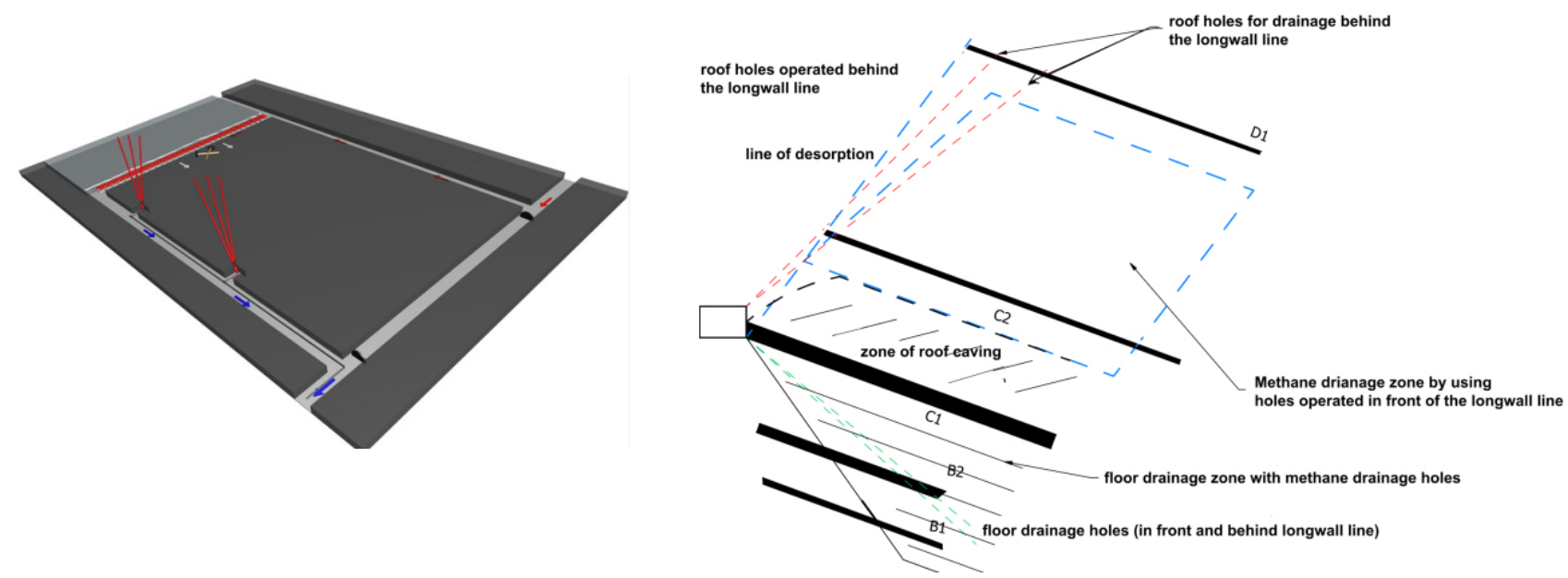

Figure 2o: Methane desorption zone and methane drainage borehole in E4 longwall panel

ings in the methane desorption zone is shown in Figure 18. According to Figure 18, gas drainage boreholes shall be drilled to be located in the optimal area. Based on the calculations, the geometric area of the optimal drainage area is 11284.81 square meters.

Accordingly, the height of the holes from the top of the $\mathrm{C} 1$ coal seam will be 15 to 20 times the thickness of the seam (see Figure 19). According to the calculations, the length of the boreholes No. 1 to 6 will be between 46-70m. It should be noted that drainage borehole angles are 32-47 degrees.

A three-dimensional schematic of the drainage drilling arrangement into a region with drainage potential is shown in Figure 20. It is clear that the drilled holes cut off the coal layers D and C2, showing higher gas emission.

We used the methane drainage boreholes information of the E3 panel for validation. The length and gradient of the E3 longwall panel is similar to the E4 panel. The length and gradient of the E3 long wall panel is 207 and 12 respectively.
As mentioned earlier, the length of the long wall and the gradient of the seam have the greatest impact on the height and methane desorption zone. We used data from 5 methane drainage stations. At each station, 4 drainage boreholes were drilled from the ventilation road (Tail Gate) with different angles to the tail gate axis. In total, we examined 20 drainage boreholes. The average concentration of the discharged methane from the boreholes showed that the boreholes drilled at an angle of 32 to 47 degrees and located in the optimal area had a higher methane concentration than the boreholes outside this area.

When draining methane from adjacent seams, it is essential to specify the zone of desorption brought on by longwall exploitation. The results showed that in order to maximize the methane drainage efficiency, the boreholes should be drilled in an area with the following specifications:

From the tail gate, with an angle of $68.1^{\circ}$ to the coal seam in roof layers (overlaying).

From the tail gate, with an angle of $34.1^{\circ}$ to the coal seam in the floor layers (underlaying). 
From the main gate, with an angle of $59.1^{\circ}$ to the coal seam in the roof layers (overlaying).

From the main gate, with an angle of $26^{\circ}$ to the coal seam in the floor layers (underlaying).

\section{Conclusion}

To improve the efficiency of methane drainage in longwall mining, it is required to identify the methane desorption zone, which facilitates the design of the drainage boreholes pattern. For the purpose of methane drainage in adjacent (overlying and underlying) coal seams, it is required to determine the boundaries of the desorption zone created by the extraction of the longwall face. Drainage boreholes should be positioned in the destressed zone without overlapping with the goaf area. In this study, the methane drainage zone in the E4 panel of the Tabas coal mine was calculated and determined using experimental equations. The results show that the length of the boreholes No. 1 to 6 must be between 46 and $70 \mathrm{~m}$. It should be noted that drainage borehole angles are 32-47 degrees.

\section{References}

Anon, (2005): Basic Design of Tabas Coal Mine Project, Report-Mining. Vol 1 of 5.

Borowski, M. and Kuczera, Z. (2018): Comparison of Methane Control Methods in Polish and Vietnamese Coal Mines. E3S Web of Conferences 35, 01004. https://doi. org/10.1051/e3sconf/20183501004

Borowski, M., Szlązak, N. and Obracaj, D. (2009): Methane Hazard Predictions in Underground Coal mining. Conference Paper, https://www.researchgate.net/publication/288 965721

Dingqi, Li. (2016): A new technology for the drilling of long boreholes for gas drainage in a soft coal seam. Journal of Petroleum Science and Engineering, 137, 107-112.

Eugeniusz, Z. and Pokryszka, Z. (2013): Investigations on methane emission from flooded workings of closed coal mines. Journal of Sustainable Mining, 12, 2, 40-45

Feng, G., Zhang, Ao., Hu, S., Guo, X., Li, Ch., Hao, Gu. and Li, Zh. (2019): A Method to Accurately Determine the Methane Enrichment Zone of a Longwall Coal Mine. Hindawi, Geofluids, Volume 2019, Article ID 2438075, 10 pages, https://doi.org/10.1155/2019/2438075

Guozhong, Hu., Jialin, Xu., Fuxi, Zh., Changchun, Zh., Wei, Q. and Yiran, Zh. (2015): Coal and Coalbed Methane CoExtraction Technology Based on the Ground Movement in the Yangquan Coalfield, China. Energies (8)6881-6897

Ilyashov, M., Diedich, L. and Nazimko, V. (2019): Prospective tendencies of coal mining risk management. Mining of Mineral Deposits, 11, 3, 40-49

Krause, E. and Skiba. J. (2014): Formation of methane hazard in longwall coal mines with increasingly higher production capacity. International Journal of Mining Science and Technology, 24, 403-407

Krause, E. and Dziurzynski. W. (2015): Designing the operation of hard coal layers in the condition of a related methane fire hazard. Central Mining Institute, Katowice, Poland, 230 p.
Lama, R.D. and Nguyen, V.U. (1987): A model for determination of methane flow parameters in coal from desorption tests. APCOM 87. Proceedings of the Twentieth International Symposium on the Application of Computers and Mathematics in the Mineral Industries. Vol. 1, pp. 275 - 282.

Li, T., Wu, B. and Lei, B. (2019): Study on the Optimization of a Gas Drainage Borehole Drainage Horizon Based the Evolution Characteristics of Mining Fracture. Energies 2019, 12, 4499

Skotniczny. P. (2013): Three-dimensional numerical simulation of the mass exchange between longwall headings and goafs, in the presence of methane drainage in a U- type ventilated longwall. Arch. Min. Sci. 58(3), 705-718.

Najafi, M. and Rafiee, R. (2019): Development of a new index for methane drainage ability of a coal seam using the fuzzy rock engineering system. Rudarsko-geološko-naftni zbornik (The Mining-Geology-Petroleum Engineering Bulletin), 34, 4, 33-45.

Qingdong, Qu., Jialin, Xu., Renlun, Wu., Wei, Qin. and Guozhong, Hu. (2015): Three zone characterization of coupled strata and gas behavior in multi-seam mining. International Journal of Rock Mechanics \& Mining Sciences. 78, 91-98

Sobolev, V., Rudakov, L., Stefanovyck, L. and Jach. K. (2017): Physical and mathematical modelling of the condition of coal and gas outbursts. Mining of Mineral Deposits, 11, 3, 40-49

Szlazak, N., Borowski, M., Obracaj, D. and Korzec, M. (2014): Selected issues related to methane hazard in hard coal mines. AGH university of science and technology press. Krakow. Poland. pp 102-105.

Szlazak, N., Borowski, M., Obracaj, D., Swolkien, J. and Korzec, M. (2014): Comparison of methane drainage methods used in polish coal mines. Arch. Min. Sci., 59, 3, 655-675.

Szlazak, N. and Swolkien, J. (2016): The effectiveness of the methane drainage of rock mass with a $U$ ventilation system. Arch. Min. Sci. 61, 3, 617-634.

Wang, G., Fan, Ch., Xu, Hao. and Wang, Rui. (2018): Determination of long horizontal borehole height in roofs and its application to gas drainage. Energies, 11, 2647. doi: 10.3390/en 11102647

Zapletal, P., Koudelková, J., Zubíček, V., Král', T. and Mokrošová, A. (2017): New method of gas drainage as a solution of danger phenomena in underground coal mines. Rudarsko-geološko-naftni zbornik (The Mining-GeologyPetroleum Engineering Bulletin), 33, 1, 7-13.

\section{Internet sources:}

URL:https://www.unece.org/fileadmin/DAM/energy/se/pp/ $\mathrm{coal} / \mathrm{cmm} / 11 \mathrm{cmm}$ oct2016/a9Methane.drainage_Poland OBRACAJ_SWOLEKIEN.pdf(accessed 24th October 2016)

URL: https://dtek.com/content/files/zbigniew-lubosik.pdf, page19, Methane Drainage and Utilization in Polish Hard Coal,

URL: http://www.unece.org/fileadmin/DAM/energy/images/ CMM/Colombia/8.1_SKIBA_PMD_Poland_GIG_Bogota_24072018.pdf, Pre-Mine Drainage in Poland, $\overline{\text { Central }}$ Mining Institute, (accessed 24th July 2018) 


\section{SAŽETAK}

\section{Određivanje desorpcije u metanskoj zoni u projektiranju postavljanja bušotina, studija slučaja panela E4 u mehaniziranome rudniku ugljena Tabas, Iran}

Podzemno rudarenje ugljena poznato je kao aktivnost s velikom emisijom metana tijekom iskapanja ugljena. Metan u samim slojevima može potencijalno biti najveći sigurnosni rizik u takvu rudarenju, a on se može spriječiti ili umanjiti raznim metodama odvođenja (drenaže). Separacija metana iz stijene najuspješniji je način kontrole rizika prouzročena tim plinom te smanjuje pojave i količine toga plina u radnome prostoru, posebice eksplozije. Metoda uključuje izradbu bušotina na jednoj strani trake za odvoz materijala s čela radilišta, u smjeru prema krovini i podini ugljenoga sloja koji se iskapa. Koncentracija plina u ugljenome sloju rudnika Tabas (Parvadeh I) procijenjena je na 16 m3/t, što je relativno visok iznos. Temeljem kartiranja izdvojeno je pet pojedinačnih ugljenih slojeva (B1, B2, $C_{1}, C_{2}$ i D), a trenutačno se vadi ugljen iz sloja C1. Kako u tome sloju i okolnim stijenama postoji visoka koncentracija metana, uveden je metanski drenažni sustav. U radu je prikazana desorpcijska površina takva sustava koja je važna i korisna varijabla u odabiru rasporeda bušotina u izdancima sloja ugljena. Tako je metanska drenažna zona u panelu E4 izračunana uporabom eksperimentalnih jednadžbi te je na osnovi rezultata određen raspored bušotina.

\section{Ključne riječi:}

ugljeni sloj, drenaža metana, zone desorpcije, bušotine, široko čelo, rudnik ugljena Tabas

\section{Authors contribution}

Ali Hosseini is a PhD student at the Department of Mining and Metallurgical Engineering, Yazd University, Iran from 2019 to present. Hosseini's research interest is coal mining. He has authored or coauthored more than 5 technical papers. Mehdi Najafi is an associate professor at Department of Mining and Metallurgical Engineering, Yazd University, Iran from 2014 to present. Najafi's research interests include underground mine planning, numerical modeling, ground control, coal mining and pillar design. He has authored or coauthored more than 25 technical papers. 